\title{
Managing with or Without Unions: A Matter of the Frame of Reference
}

\author{
Idowu Onabanjo \\ Department of Business Administration \\ McPherson University, Seriki Sotayo, Ogun State, Nigeria
}

\begin{abstract}
It is possible to manage with or without unions depending on the frame of reference that management embraces. However, there are advantages and disadvantages to whichever frame of reference a management chooses. Managing without unions is like a government without opposition. It is unitary; it is autocratic in its worst, paternalistic at its best. Managing with unions is pluralistic and requires a process of accommodating various stakeholders.
\end{abstract}

Key words: manage with, manage without, unions, matter of frame of reference, unitary, pluralistic

\section{INTRODUCTION}

As a result of the industrial revolution which started in Britain in the $\mathrm{C} 17$ th, many changes were brought about. Technology changed, manufacturing processes changed, mass production was possible and profits increased. Manufacturers became enormously wealthy but the lot of workers was not improved. Capitalists were driven to make more and more profits at the expense of workers. The immediate effect of industrialization upon workers was that they were drawn together in large numbers and at the same time in considerable distance from their employers. This process of alienation was further compounded by the fact legal contrivance making fund available for the requirement of production made numerous people to be co-owners of a company. Division of labour dispenses with the need to have relatively expensive skilled labour. Jobs became so simple that workers could be brought straight from the street to start work on a production line. The jobs became repetitive and boring. To ensure work was done properly, close supervision became the rule and work was dehumanized as a result. To make optimum use of the expensive machinery, it was injudicious to leave them idle for a long time hence shift work became desirable and some workers became nocturnal against their wishes. Under this system the workers totally depended upon wages and referred to industrial capitalism as 'wage slavery'. Trade unions as we know them today evolved gradually as a permanent opposition in industry. It will be seen that they have come to work within the system, to change the relationships originally imposed or threatened. (Whitehead, 1977)

Hyman (1981) in his introduction comments that social relationships are essentially dynamic; what exists at any point in time is the product of past actions and relationships and contains in turn the potential for future development. To do justice to this dynamic character, any valid social analysis must contain a historical dimension. The foregoing introduction is the historical dimension.

\section{RATIONALE FOR TRADE UNIONISM}

There is a limit to individual action of the worker. Workers avail themselves the opportunity of equalizing their feeble power with the 'almighty' power of the employer, by forming a union, speak with one voice with collective will knowing the employer can do away with an individual worker but it would be foolhardy to attempt to do away with the entire workforce. This is 
summed up in the dictum 'In unity there is strength'. The benefit to the individual workers is that, through the union to which they belong they participate in making decisions affecting them in their organization. Management on the other hand saves time and effort in dealing with individual worker.

Clegg (1951, p.76) in his defence of trade unions' limited democracy points out that the primary task of a union is to protect its members and to protect them against someone - the employer. The trade union is thus industry's opposition - an opposition which can never become a government.

There is need for an opposition in industry. Not only would industry be autocratic without it .... The main activities of the union can well be interpreted as opposition, as opposition to the wage the employer pays, the conditions of the establishment, the way he and his agents treat his men, in the endeavour to obtain improvements. And the union has incentive to oppose, discover, if possible, the shortcomings of the employer. For if employers had no shortcomings there would be no need for trade unions - as we know them.

\section{Trade Unions As Seen by Scholars/Writers}

The approach of the employer or the manager to industrial democracy is radically different .... He may have genuine interest in the welfare of his staff and be convinced that the best work arises from willing cooperation, and yet strive to exclude trade unions as outsiders who have no claim to interfere in its establishment, and set up welfare schemes, internal representative organizations or co-partnership schemes to achieve his purposes and to avoid the need for unions .... The 'progressive' employer welcomes trade unions, encourages his workers to join them, perhaps grants them the security of a closed shop, takes pains to keep on good terms with the union officials, pays a full-time elected secretary of the workers' side of the works council to devote his time to looking after the interests of the workers; and the reason for it is that he feels that willing cooperation can only arise out of independence. The trade union may be allowed to oppose him and to protect the worker, because the employer thinks that union opposition may be led to play its part in achieving genuine cooperation Clegg (1951, p82).

Flanders (1970, p20) claims that trade unions exist to promote sectional interests - the interests of the section of the population they happen to organize....There is nothing selfish or slightly disreputable about this; it is an essential part of the democratic process....The activity to which they devote most of their resources and appear to rate most highly is collective bargaining. So the question we have to ask is what purposes do unions pursue in collective bargaining? He goes further to say that, one of the principal purposes of trade unions in collective bargasining is regulation and control because unions and their members are interested in the effect of the rules made by collective bargaining, which is to limit the power and authority of employers and to lessen the dependence of employees on market fluctuations and the arbitrary will of management.

Cole (1913, p73) regarded trade unions as co-partners of industry, when he suggested that in studying the future of trade unionism, we shall be regarding it as the future partner of the State in the control of industry - no longer as a mere fighting organization, existing only because the employer is there to combat, but as a self-governing, independent corporation with functions of its own- the successor of capitalism as well as its destroyer. 
Of the section of the population they happen to organize....The activity to which they devote most of their resources and appear to rate most highly is collective bargaining. So the question we have to ask is what purposes do unions pursue in collective bargaining?

\section{Two Views of Trade Unionism}

Cole (1939, pp. 535-6) affirms that there are two views of the purpose of trade union even within the Trade Union movement. Class-conscious proletarians, holding Socialist (or in some countries Anarchist or Syndicalist) opinions, and seeking to weld the whole working class together into a solid force for the overthrow of capitalism, regards the trade unions as the instinctive expression of the class struggle which is inherent in the wage relationship between capitalist and labour, and can be transcended only by the supersession of capitalism itself. Another view of trade unionism is held among the skilled workers and among professional and other non-manual workers who enjoy the superiority of status or income. This view is to the effect that a trade union exists to protect and advance the interests of a defined group of workers who possess some special skill or other mark of distinction from the general mass of labour, so that they can hope to secure better terms of employment than would be possible if each man acted alone by creating a limited monopoly of labour in order to improve its price. Here there is no desire to change the economic system nor is there any desire to build up a solid combination of the whole working class.

Otobo (2000) splits the former view into two, explaining that it depends on whether or not the action is contemplated under capitalist or socialist regime. Under a capitalist regime, apart from improving the lot of labour, it is duty of the revolutionary trade union to unite, discipline and educate the masses with a view to abolishing capitalism and establishing socialism. Under the socialist regime, the trade union should consolidate the gains of the revolution. The latter view is the western or capitalist view and this is not materially different from that of Cole. Here trade union works within capitalism and strives to improve the working lives of their members.

\section{MANAGING WITH UNIONS}

Managing with unions requires management to make certain decisions in conjunction with union. There are some decisions which management considers its prerogatives. Under the mechanism known as collective bargaining, decisions on divergent issues are made. Such decisions are codified in collective agreement. Under joint consultation decisions on issues of mutual interests are made. These decisions are joint understandings short of signed agreement. Management initiates the implementation of collective agreement and the union monitors the implementation to ensure the agreement is followed to the letter.

\section{MANAGING WITHOUT UNIONS}

Through the union, the interest of the members are defended and protected but without a union, there is no guarantee, that management will be fair, that workers will not be shortchanged. IBM, Hewlett Packard and other large multinationals such as Black and Decker, Gillette, Mars, Polaroid, Texas Instruments, Nestle, Marks \& Spencer are non-union companies. Managing without unions is autocratic, unilateral and the temporary benefits workers may enjoy, cannot be guaranteed in future. Management may start well i.e. being fair but the vagaries of the economy may compel it to discontinue being fair to its employees. A case in point is Marks \& Spencer-manufacturer without factories. As culled from Blyton and Turnbull, (1998, pp.245-50)

'Do as you would be done by' (Sieff, 1990;84) is the golden rule of the company's human relations policy. As the former Chairman Lord Sieff explained, any policy derived from the 'law and the prophets' carries with it a strong moral obligation. Good human 
relations at work pay off; they are of great importance if a business is to be efficiently run' (ibid:56). This is certainly true of Marks \& Spencer, a company hailed by Peter Drucker (1974:98) as one of the most efficient in the world, and a few years ago voted Britain's best managed company for the third year in succession by a panel of institutional investors, captains of industry and business journalists (Financial Times, 19 March 1997). It is on record that since the late 1960s Marks and Spencer's approach to human relations has been popularized as an alternative to the collectivist, institutionalized approach based on the Whitley and later Donovan model, as Lord Sieff (1986:82) points out in his memoirs. He states that when employees are recruited to Marks and Spencer they are given a 'Welcome Pack' containing information on the company and its principles. It is here they first encounter the company's commitment to fostering good human relations. A second booklet, "Facts for New Staff' gives details of employees' conditions of employment. These include competitive rates of pay, noncontributory pensions, profit sharing and extensive medical care. Female employees, for example, are offered breast and cervical screening, while male employees can view a video and read a company leaflet on testicular self examination. Everyday health and safety is covered in another booklet, 'The Right Move' which advises on such matters as the lifting of heavy boxes), while "Personal Safety' offers employees advice on going to and from work.

Tse (1985:118) argues that it is a misrepresentation to simply label Marks \& Spencer's approach to human relations as paternalism. Tse goes further to remark that the company's human relations policy includes respect for the individual, attention to the problems of individuals at work, full and frank communications, the recognition of people's effort and contribution, and continuous training and development. Tse (1985:122) goes further to say that as trade unions are concerned Marks \& Spencer's approach can best be described as 'pre-emptive', straightforwardly non-union rather than explicitly anti-union. Put differently, the approach is one of substitution rather than suppression of union activity (Beaumont, 1987:130) adds, Marks \&Spencer's Director of Personnel remarks that the company appreciates that in companies that are willing or unable to provide more than the basic terms and conditions for their employees trade unions do have a valuable role to play in negotiating for their members and Tse punctuates that with such care and attention lavished on the promotion of good human relations, 'unionism simply finds it difficult to flourish in St Michael Soil'

The policy as pictured above lasted till 1991 when in contrast to its human relations policy Marks and Spencer announced 850 redundancies, which in some quarters was seen to herald 'the end of Marks \& Spencer's unofficial commitment to its staff of a job for life' As Lord Sieff (1990:64-5) makes it clear, any such commitment on the part of $M \& S$ was always implicit rather than explicit, but the effect on the staff concerned was nonetheless traumatic.

Financial Times (30 April 1991) wrote 'The Baker Street headquarters in London was gripped by gloom and confusion' while city analysts predicted 'the transition from a safe, job-for-life type organization into a meritocracy. To a certain extent, M\&S has always been carrying a lot of fat and it is the first time that it has gone on a diet' (ibid). (Financial Times, 11 May and 18 May 1991) reported that M\&S has been keen to quash any rumours that the company plans to cut welfare, adopt a less caring approach or change its culture, but in July 1996 the company stopped providing free breakfasts (on 
the grounds that not all staff enjoyed this 'perk') and the very notion of a full-time employee was abolished (staff are now paid for hours worked rather than a set monthly salary).

My stand is that, in an organization where there is a union, workers make demands from management through the union but where there is no union, workers are at the mercy of management. Whenever management appears to be benevolent it is a mere truce when it is not convenient for management to be so benevolent, workers have no alternative other than to resign and in a situation of high rate of unemployment it is suicidal so to do. This exactly was what happened in Marks and Spencer!

\section{FRAME OF REFERENCE}

The way one perceives a phenomenon determines to a very large extent how one expects others to treat the phenomenon. It is a form of stereotype, a mindset or an attitude that determines behaviour. Just as we have theory $\mathrm{X}$ managers and theory $\mathrm{Y}$ managers based on the respective assumptions of theories $\mathrm{X}$ and $\mathrm{Y}$ as propounded by Mc Gregor.

Salamon (1992) relying heavily on the work of Fox 1966 and 1973 and Hyman (1975) in describing the nature of employment organizations considers the unitary, pluralistic and the Marxist perspectives with a caveat that there is as much variation within each perspective as there are differences between them.

\section{The Unitary Perspective}

The unitary perspective emphasizes the organization as a coherent and integrated team 'unified by a common purpose'. It can encompass either an authoritarian or paternalistic approach to the role of management. It is based on the assumption that in the organization there is a single authority/loyalty structure and members of the organization share a set of common values, interests and objectives. Management's prerogative (its right to manage and make decisions) is legitimate, rational and accepted and any opposition to it is seen as irrational. The organization in such a situation is in basic harmony and conflict is unnecessary and exceptional. Conflict is perceived as an irrational activity. Any transgression of management's rule is viewed as aberrant rather than non-conformist behaviour. It is also believed that when conflict arises it is primarily frictional rather than structural and is caused by clashes of personalities within the organization, poor communication by management of its plans and decisions, a lack of understanding on the part of employees that management decisions and actions are for the benefit of all, or caused by agitators. Management's approach to resolving such conflict is often based on authoritarian or paternalistic style. The use of coercion is regarded as a legitimate use of managerial power. Trade unions are regarded as an intrusion into the organization from outside which competes with management for the loyalty of members. Many managers perceive trade unions as little more than an historical anachronism that had a role within the frame-work of nineteenth century employer/employee relations but, with enlightened management in the twentieth century, are no longer necessary to protect the employees' interests. It is to be noted that management may be disposed to accept the existence of unions in the determination of terms and conditions of employment (market relations), it is certainly reluctant to concede any role for trade unions in the exercise of authority and decision making within the organization (managerial relations). The existence of trade unions and collective bargaining is suffered, rather than welcomed and is to be resisted wherever possible. Unitary perspective of organizations is predominant among managers and the view is referred to as managerial ideology. Managers hold on to this view because it legitimizes managers' authority role as being in the best interest of the organization. 


\section{The Pluralist Perspective}

Trade unions exist in organizations as one of the sectional interests and this view of organizations is the received orthodoxy in many western societies. Fox believes that with this perspective, there is relatively widespread distribution of authority and power within the society, also that there is a separation of ownership from management, a separation of political and industrial conflict, and an acceptance and institutionalization of conflict in both spheres. The organization is perceived as being multi-structured and competitive in terms of groupings, leadership authority and loyalty, and this, Fox argues gives rise to a complex of tensions and competing claims which have to be 'managed' in the interests of maintaining a viable collaborative structure. The underlying assumption of this approach, therefore, is that the organization is in a permanent state of dynamic tension resulting from inherent conflict of interest between the various sectional groups and requires to be managed through a variety of roles, institutions and processes. Conflict between management and employees is both rational and inevitable. Consequently conflictual behaviour may arise in respect of both specific situations and general 'management principles.'

Under this perspective there has to be an acceptance of the need for shared decision making and the legitimacy of management's role is not automatic but must be sought and maintained by management itself (management by consent rather than management by right). Fox argues that the interest groups in the organizations have right of free association as they can assert their aspirations and claims and it is the role of law to define the limits of socially acceptable collective actions and use them.

Trade unions do not of themselves, cause conflict within organizations but simply provide a highly organized and continuous form for sectional interests which would exist anyway.

\section{The Marxist Perspective}

This perspective is based on the capitalist society where there are the haves and the have-nots, where a group has the authority to issue orders while the other and larger group has the duty to obey such instructions/orders. A capitalist society is a class society. The mere exercise of managerial authority is a potential source of conflict. The contract of employment is said to be entered into by equals but from this perspective challenges the notions of both 'freedom' and 'equality'. The application of the law in respect of the contract of employment is perceived as being asymmetrical. As Hyman points out the obligations undertaken by the employer are relatively precise and specific whilst the obligations on the worker.... Are imprecise and elastic. Hyman believes that in the eye of the law "equality" of the employment contract gives the employer the right to issue orders, while imposing on the worker the duty to obey hence in Marxist perspective the law is supportive of management's interest and position rather than being an independent referee between competing interests.

It has been stated earlier on that a frame of reference is a mindset, hence a management that embraces the unitary perspective assumes trade unions are intrusion in industry. Trade unions compete with management for the loyalty of workers. Trade unions restrict management's autonomy. Trade unions are cost raising institutions. With these assumptions such a management will either be anti-union or avoid unions by whatever means.

A management that embraces pluralistic perspective realizes that trade union is one of the sectional interest groups in the industry and the relationship for the survival of the organization can only be symbiotic rather than being parasitic hence ways of managing the interest groups should the focus of management. 


\section{WHY ARE MANAGEMENTS ANTI-UNION OR WHY DO THEY AVOID UNIONS?}

Managements are anti-union or do not want unions and they adopt any conceivable device to achieve this because, managements want to be in charge at all cost. The effect of the rules made by collective bargaining is to limit the power and authority of employers and it lessens the dependence of employees on market fluctuations and the arbitrary will of management.

\section{Union Avoidance Techniques}

Management employ human resource management strategies and practices to keep unionization away from their companies. Practices such as promotion from within, put in place an influential personnel - human resource department, and above-average pay and benefits. In other words, employers offer most of the things a union can offer except that employers cannot duplicate independent employee voice that a union provides. Another employer tactic is the double-breasted arrangement which refers to what happens in multi-plant companies where established unions are recognized while unions in newer plants are not so recognized.

Management's perspective is dynamic depending on varying circumstances. Barbash reports that 'many tough bargainers (among employers) prefer the union to a situation where there is no union. Most of the employers in rubber, basic steel and the automobile industry fall in this category.' The idea then was that an effective union could help masses and communicate the interests of employees to management, thus helping management make better decisions. But product-market pressures, such as foreign competition and deregulation have contributed to increasing employer resistance to unions.

\section{FACTORS THAT MAKE THE FORMATION OF A UNION IMMINENT}

Otobo (1995) in one of his polemics states the factors that make the formation of a trade union imminent are

1) There must be widespread wage employment

2) There must be widespread grievances

3) The individual person or prospective worker must be both physically and legally free to move about for wage employment and

4) Workers must solely or predominantly depend on their wages to survive.

At the beginning of industrialization occasioned by the industrial revolution, there were widespread wage employment, grievances were widespread to the extent that the workers involved referred to industrial capitalism as wage slavery, prospective workers were both physically and legally fit to move about in search of employment since the breakdown of feudalism and workers left their homes for urban centres hence they depended solely or predominantly on their wages for survival. Whitehead (1977) admirably gave this account.

\section{CONCLUSION}

If management embraces unitary perspective as its frame of reference, it will regard a trade union as an unnecessary intrusion into its organization, hence it will be anti-union or avoid unionism. In other words, it will manage without unions. If on the other hand, it embraces pluralistic perspective, it will consider a trade union as one of the interest groups in its organization, hence it will manage with unions.

However, if workmen are driven to a situation, whereby those things that management has been using to keep unions away are now withdrawn as it happened in Marks and Spencer if those conditions above are met workmen will form trade unions. 


\section{References}

Blyton, P. and Turnbull, P (1998) The Dynamics of Employee Relations London: Macmillan Press Ltd.

Clegg, H. A. (1951) in McCarthy, W. E. J. (ed.) Trade Unions, Penguin, 1972.

Cole, G. D. H. (1939) British Trade Unionism Today, London: Gollanz

Cole, G. D. H. (1913) in McCarthy, W. E. J. (ed.) Trade Unions, Penguin, 1972.

Flanders, A. (1970) in McCarthy, W. E. J. (ed.) Trade Unions, Penguin, 1972.

Hyman, R. (1981) Industrial Relations: A Marxist Introduction, London: Macmillan Press Ltd.

Otobo, D. (1995) The Trades Union Movement in Nigeria, Lagos: Malthouse Press Limited.

Otobo, D. (2000) Industrial Relations: Theory and Controversies, Lagos: Malthouse Press Limited.

Salamon, M. (1992) Industrial Relations, UK: Prentice Hall International

Whitehead, K. (1977) Industrial Relations, London: Macmillan Press Limited. 